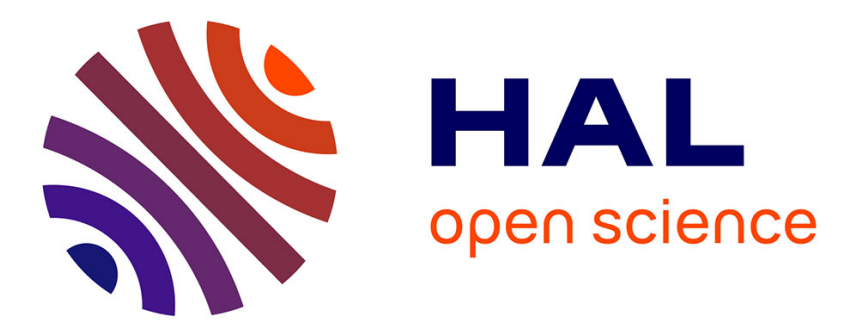

\title{
Gene expression profile of prostate cancer cell lines: Effect of nerve growth factor treatment
}

S. Sigala, S. Bodei, C. Missale, D. Zani, C. Simeone, S. Cosciani Cunico, P.F.

Spano

\section{- To cite this version:}

S. Sigala, S. Bodei, C. Missale, D. Zani, C. Simeone, et al.. Gene expression profile of prostate cancer cell lines: Effect of nerve growth factor treatment. Molecular and Cellular Endocrinology, 2008, 284 (1-2), pp.11. 10.1016/j.mce.2007.12.015 . hal-00531977

\section{HAL Id: hal-00531977 \\ https://hal.science/hal-00531977}

Submitted on 4 Nov 2010

HAL is a multi-disciplinary open access archive for the deposit and dissemination of scientific research documents, whether they are published or not. The documents may come from teaching and research institutions in France or abroad, or from public or private research centers.
L'archive ouverte pluridisciplinaire HAL, est destinée au dépôt et à la diffusion de documents scientifiques de niveau recherche, publiés ou non, émanant des établissements d'enseignement et de recherche français ou étrangers, des laboratoires publics ou privés. 


\section{Accepted Manuscript}

Title: Gene expression profile of prostate cancer cell lines:

Effect of nerve growth factor treatment

Authors: S. Sigala, S. Bodei, C. Missale, D. Zani, C. Simeone, S. Cosciani Cunico, P.F. Spano

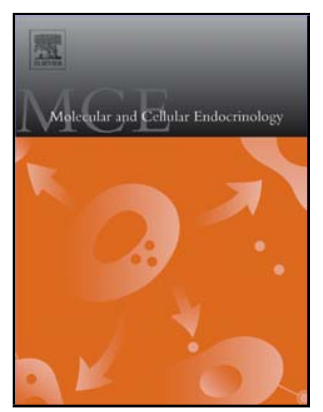

PII:

DOI:

Reference:

To appear in:

Received date:

Revised date:

Accepted date:
S0303-7207(08)00002-6

doi:10.1016/j.mce.2007.12.015

MCE 6780

Molecular and Cellular Endocrinology

3-4-2007

$19-12-2007$

22-12-2007

Please cite this article as: Sigala, S., Bodei, S., Missale, C., Zani, D., Simeone, C., Cunico, S.C., Spano, P.F., Gene expression profile of prostate cancer cell lines: Effect of nerve growth factor treatment, Molecular and Cellular Endocrinology (2007), doi:10.1016/j.mce.2007.12.015

This is a PDF file of an unedited manuscript that has been accepted for publication. As a service to our customers we are providing this early version of the manuscript. The manuscript will undergo copyediting, typesetting, and review of the resulting proof before it is published in its final form. Please note that during the production process errors may be discovered which could affect the content, and all legal disclaimers that apply to the journal pertain. 


\section{GENE EXPRESSION PROFILE OF PROSTATE CANCER CELL LINES:}

\section{EFFECT OF NERVE GROWTH FACTOR TREATMENT}

S.Sigala ${ }^{\text {a }}$, S. Bodei ${ }^{\text {a }}$, C. Missale ${ }^{\text {a }}$, D. Zani ${ }^{b}$, C. Simeone ${ }^{\text {b }}$, S. Cosciani Cunico ${ }^{\text {b* }}$, P.F. Spano ${ }^{a^{*}}$.

${ }^{\text {a }}$ Section of Pharmacology, Department of Biomedical Sciences and Biotechnology, V.le Europa 11, Brescia ${ }^{\mathrm{b}}$ Division of Urology, P.le Spedali Civili 1, Brescia; University of Brescia Medical School, Brescia, Italy.

* S.C.C. and P.F.S. contributed equally to this work

Please send correspondence to:

Dr. Sandra Sigala

Pharmacology

Dept. of Biomed. Sci. and Biotec.

University of Brescia Medical School

V.le Europa 11

25123 Brescia (Italy)

Tel: int $+030+3717515$ Fax: int $+030+3717529 \quad$ Email: sigala@med.unibs.it 
Key words : Nerve Growth Factor, DU145 cell line, PC3 cell line, microarray analysis, quantitative RT-PCR.

\section{SUMMARY}

A dysregulation of the Nerve Growth Factor (NGF)-mediated control of prostate cell growth is associated with the malignant progression of prostate epithelial cells. Exogenous NGF induced in

prostate cancer $(\mathrm{PCa})$ cell lines DU145 and PC3 the expression of $\mathrm{p} 75^{\mathrm{NGFR}}$, accompanied by a reduction of the cell malignancy. The aim of this study was to analyze the profile of NGF-regulated genes the PCa cell line DU145 by using the cDNA microarray technique.

NGF treatment of DU145 cells decreased the expression of 52 known genes, while the expression of 40 known genes was increased. NGF treatment of the DU145 cell line modified the expression profile of clusters of genes involved in invasion and metastasis, in cell proliferation and apoptosis, inflammation, cell metabolism and transcriptional activity. Interestingly, NGF induced the same pattern of gene modifications in both PCa cell lines. Data presented here may help to identify gene/proteins that dispose to PCa progression and to assess future markers that could allow the development of new clinic diagnostic and therapeutical approaches. 


\section{INTRODUCTION}

Evidence generated over the past years suggests that growth factor-mediated pathways are modified during prostate cancer (PCa) development and advancement (reviewed in Djakiew, 2000). This dysregulation has been implicated in tumor progression and in the metastatic colonization which, in turn, involve cellular proliferation, adhesion and motility (Montano and Djamgoz, 2004) Therefore, analysis of the role of different growth factors and their receptors in the control of these mechanisms may help to clarify the pathogenesis and the progression of $\mathrm{PCa}$.

Nerve Growth Factor (NGF) plays a physiological role in the control of prostate epithelial cell growth and differentiation (Macgrogan et al., 1992; Paul et al., 1996; Harper, 1999). The observation that NGF production is progressively lost in PCa advancement (Paul et al., 1996; Montano and Djamgoz, 2004) suggests that this neurotrophin plays a role in PCa development. Analysis of NGF receptor expression showed that $\mathrm{p} 75^{\mathrm{NGFR}}$ expression is decreased in PCa and that the extent of $\mathrm{p} 75^{\mathrm{NGFR}}$ loss is related to PCa progression (Pflug et al., 1992). By contrast, trkA is maintained in all grades of PCa (Pflug et al., 1995), and promotes mitogenesis and invasion (Festuccia et al., 2007). Thus, it could be proposed that, while trkA mediates the mitogenic effect of $\mathrm{NGF}$, co-expression of both $\mathrm{p} 75^{\mathrm{NGFR}}$ and trkA represents a crucial condition for the antiproliferative effect of NGF, leading to the suggestion that a dysregulation of NGF-mediated control of prostate growth may be associated with PCa progression (Pflug and Djakiew, 1998). On this line, it has been recently pointed out that the NGF 'circuitry' in PCa as atarget for the development of novel therapeutic agents (Papatsoris et al., 2007).

We have previously shown that NGF treatment induces the expression of $\mathrm{p} 75^{\mathrm{NGFR}}$ and has antiproliferative effects in different tumors including pituitary adenoma (Missale et al., 1993), small cell lung carcinoma (Missale et al., 1998) and thyroid tumor (Paez-Pereda et al., 2000). We have also reported that PCa cell lines are differentiated by NGF into a less malignant phenotype (Sigala et al., 1999; Sigala et al., 2002). In particular, the DU145 and PC3 cell lines responded to NGF with a decrease of telomerase activity and with the expression of functionally-active androgen 
and $\mathrm{p} 75^{\mathrm{NGFR}}$ receptors. These molecular changes were accompanied by the reduction of the cell proliferation rate both in vitro and in vivo and by the reduction of the in vitro invasive capacity (Sigala et al., 1999; Sigala et al., 2002). In line with these data, the role of $\mathrm{p} 75^{\mathrm{NGFR}}$ as a tumor suppressor molecule in the PCa cell line PC3 has been recently emphasized (Nalbandian et al., 2005). Indeed, transfection of $\mathrm{p} 75^{\mathrm{NGFR}}$ into PC3 cells has been shown to modulate the expression of genes that are critically involved in cell adhesion, apoptosis, metastasis, signal transduction and transcription (Nalbandian et al., 2005). Regulation of molecular events leading to anchorageindependent growth necessary for invasion involves a temporal and spatial coordination of molecules that are causally involved in the process (Hoon et al., 2006). Thus, identification of the complete pattern of gene alterations and molecular events leading to cancer progression and metastasis is a great challenge in PCa research, that may help the development of new diagnostic and therapeutical approaches. On this basis, the aim of this study was to analyze the profile of NGFregulated genes the PCa cell line DU145 by using the cDNA microarray technique. 


\section{MATERIALS AND METHODS}

Cell culture and NGF treatment. PC3 and DU145 cells were purchased from the American Type Culture Collection (ATCC) (LGC Promochem, Sesto San Giovanni, MI, Italy) and maintained in culture as suggested by ATCC. Media and supplements were purchased from Celbio (Milano, Italy). Human recombinant NGF was purchased from Sigma Aldrich Italia (Milano, Italy). On the bases of our previous data (Sigala et al., 1999; Sigala et al., 2002), DU145 cells were treated with $50 \mathrm{ng} / \mathrm{ml}$ NGF for 8 days, while PC3 cells were exposed to $100 \mathrm{ng} / \mathrm{ml}$ NGF for 14 days. At these concentration and times, the differentiating effects of NGF were maximal, as shown by the extent of inhibition of cell proliferation and telomerase activity. PC12 cells were kindly provided by Prof. Calissano (Neurobiology Institute, CNR, Roma, Italy) and grown in RPMI 1640 medium supplemented with $10 \%$ horse serum, $5 \%$ fetal calf serum, $4 \mathrm{mM}$ glutamine and $100 \mathrm{U} / \mathrm{ml}$ penicillin/streptomycin.

Cell proliferation rate. Cell proliferation rate was evaluated as previously described (Sigala et al., 2002). Briefly, untreated and NGF-treated DU145 and PC3 cells were detached from plates and plated again at the density of $5 \times 10^{5}$ cells/well. Twenty-four hours later, cells were washed with phosphate-buffered saline (PBS), released from the culture wells with trypsin-EDTA and added with $\mathrm{Ca}^{++}$and $\mathrm{Mg}^{++}$-free PBS containing $0.25 \%$ trypan blue to stain non-viable cells. Cell suspensions were dropped in a hemocytometer chamber and the viable cells were blind counted under a phase contrast microscope by two different operators. Results are the mean \pm SEM of six different dishes for each cell culture. The number of cells for each dish was the mean \pm SEM of at least five different counts. Data analysis and graphics were obtained using GraphPad Prism 4 software. The one way analysis of variance (ANOVA) followed by the Student's t test was used for statistical evaluation of differences, considering $p<0.05$ as threshold for significant difference.

Immunocytochemistry. Experiments were carried out as previously described (Sigala et al., 2002). Briefly, untreated and NGF-treated DU145 and PC3 cells and control PC12 cells were plated on poly-L-lysine-treated coverslips. Twenty-four hours later, cells were fixed for 5 min 
at $-20^{\circ} \mathrm{C}$ in methanol and washed in phosphate buffered saline (PBS). Endogenous peroxidases were inactivated at room temperature for $30 \mathrm{~min}$ with $1 \%$ hydrogen peroxide solution. Cells were permeabilized in PBS containing 10\% normal donkey serum and $0.2 \%$ Tryton X-100 and incubated with a 1:1000 dilution of $\mathrm{p} 75^{\mathrm{NGFR}}$ goat polyclonal antibody (C-20, epitope mapping the $\mathrm{C}$ terminus of human p75 ${ }^{\text {NGFR }}$; Santa Cruz Biotechnologies, Heidelberg, Germany) (Nickerson Poulin et al., 2006; Hasan et al., 2005; Ohrt et al., 2004). After extensive washes, the donkey anti-goat biotinylated secondary antibody (Dako S.p.A., Milano, Italy) was added. Signal detection was carried out with the ABC kit (Dako S.p.A.). PC12 cells were used as positive internal control, while the negative control was represented by untreated DU145 and PC3 cells (Pflug et al., 1992; Sigala et al., 2002). Moreover, omission of the primary antibody (not shown) and replacement of the primary antibody with goat normal serum were also used to define the non-specific signal.

RNA isolation. Total RNA was isolated from untreated and NGF-treated DU145 and PC3 cells (about $10^{7}$ cells) using the RNeasy kit (Quiagen, Milano, Italy) and digested with the RNase-Free DNAse set (Quiagen, Milano, Italy), according to the manufacturer protocol. RNA quality of samples was tested by RNA electrophoresis and RNA LabChip analysis (Agilent Technologies, Palo Alto, USA) to ensure RNA integrity.

Microarray analysis. Five $\mu \mathrm{g}$ of RNA from untreated and NGF-treated DU145 cells were sent to the service provider RZPD (Deutsches Ressourcenzentrum für Genomforschung GmbH, Berlin, Germany) to perform the Affimetrix Expression Profile. Briefly, the quality control of total RNA was run again, using the Eukaryote Total RNA Nano assay (Agilent Technologies) and RNA was quantified with the NanoDrop technology (Agilent Technologies). Synthesis of cDNA for each sample and in vitro transcription was done with the Ambion's Message Amp II kit, while the quality control of labelled cRNA was done with the messenger RNA (mRNA) Smear Nano Assay (Agilent Technologies), followed by the NanoDrop technology for exact quantification. The hybridization solution was prepared according to the Affymetrix GeneChip Expression Analysis Technical Manual. Biotinylated cRNA (60 $\mu \mathrm{g} / \mu \mathrm{l}$ final concentration) was hybridised on the Human 
Genome U133 Plus 2.0 Array GeneChip for $16-18 \mathrm{~h}$ at $45^{\circ} \mathrm{C}$ and $60 \mathrm{rpm}$ (Hybridization Oven 640, Affymetrix UK Ltd). Spike controls for $b i o B, b i o C$, bioD and cre at concentrations of 1.5, 5, 25 and $100 \mathrm{pM}$ were included according to the manufacturer's instructions (Affymetrix UK Ltd, Cat. No. 900454). Array washing and staining were performed with a fluidics station (GeneChip Fluidics Station 400, Affymetrix UK Ltd), which is controlled by the Affymetrix's software GeneChip Operating System (GCOS), using protocols EukGe_WS2v4 for the test3-array. Scanning of chips was performed with the GeneChip Scanner 3000 (Affymetrix UK Ltd), which is controlled by Affymetrix's software GeneChip Operating System (GCOS), that performed also the primary data analysis. The microarray suite software package (MAS 5.0; Affymetrix UK Ltd) was used to evaluate probe set signals of the array.

Microarray statistical analysis. Starting from the raw data files (.cel files), analysis was performed at the service provider using the Affymetrix Microarray Suite Version 5.0 software. Briefly, signal intensities were scaled to identical trimmed mean intensity of all scaled signals, according to standard procedures (Affymetrix Microarray Suite User's Guide MAS 5.0). For all probe sets of each chip, the median signal was scaled to a target intensity $=100$ in the MAS 5.0 software. Default values for the present/absent filter were alpha $1=0.05$, alpha $2=0.065$ for 11 probe pairs/probe set. Genes with a $P$-value $<0.04$ were detected as 'present' call, $P$-value $>0.06$ obtained 'absent' calls and $P$-values ranging from 0.04 to 0.06 were 'marginally present'.

Q-RT-PCR. One $\mu \mathrm{g}$ of total RNA from untreated and NGF-treated DU145 and PC3 cells was transcribed into cDNA using murine leukemia virus reverse transcriptase (Promega Italia, Milano, Italy) and oligod $\mathrm{T}_{15-18}$ as a primer (final volume: $50 \mu \mathrm{l}$ ). Parallel reactions containing no reverse transcriptase were used as negative controls to confirm the removal of all genomic DNA. Human specific primers were designed using the Primer3 software (http://frodo.wi.mit.edu) (Rozen and Skaletsky, 2000). The sequences of the primers used are reported in Table 1.

Amplification and detection were performed with the iCYCLER iQ Real Time PCR Detection System (BioRad Italia, Milano, Italia); the fluorescence signal was generated by SYBR Green I. 
Samples were run in triplicate in a $25 \mu 1$ reaction containing $12.5 \mu 12$ x SYBR Green Master Mix (BioRad Italia), 12.5 pmol of each forward and reverse primer (Table 1) and $2 \mu$ l of diluted cDNA. Each PCR experiment included serial dilutions of a positive control for construction of the calibration curve, a positive and a negative DNA sample, and water blanks. The PCR program was initiated by $10 \mathrm{~min}$ at $95^{\circ} \mathrm{C}$ before 40 cycles, each for $15 \mathrm{sec}$ at $95^{\circ} \mathrm{C}$ and $1 \mathrm{~min}$ at $60^{\circ} \mathrm{C}$. A subsequent dissociation curve analysis checked the specificity of products. Gene expression levels were normalized to $\beta$ actin expression and data are presented as the fold change in target gene expression in NGF-treated cells normalized to the internal control gene ( $\beta$ actin) and relative to untreated cells. Results were estimated as $\mathrm{Ct}$ values, the $\Delta \mathrm{Ct}$ was calculated as the mean of the $\mathrm{Ct}$ for the target gene minus the mean of the $\mathrm{Ct}$ for the internal control gene. The $\Delta \Delta \mathrm{Ct}$ represented the mean difference between the $\Delta \mathrm{Ct}$ of untreated cells minus the $\Delta \mathrm{Ct}$ of NGF-treated cells. The N-fold differential expression in the target gene of NGF-treated cells compared to untreated cells was expressed as $2^{-\Delta \Delta \mathrm{Ct}}$. Data analysis and graphics were obtained using GraphPad Prism 4 software and were the results (mean \pm SEM) of three different experiments run in triplicate for each gene in untreated and NGF-treated cell lines. 


\section{RESULTS}

\section{Effect of NGF on DU145 and PC3 cells}

DU145 cells were exposed to $50 \mathrm{ng} / \mathrm{ml}$ NGF for 8 days and PC3 cells were exposed to $100 \mathrm{ng} / \mathrm{ml}$ for 14 days. These concentrations and times were chosen on the basis of previous data showing that NGF progressively induces cell differentiation with a maximal effect in these conditions. Cell proliferation and $\mathrm{p} 75^{\mathrm{NGFR}}$ expression were measured as an index of differentiation. As shown in Fig. 1A and according to our previous data, exposure of these cell lines to NGF resulted in the reduction of their cell proliferation rate, which was about 55\% inhibited in DU145 cells and 45\% inhibited in PC3 cells. NGF treatment resulted in the expression of $\mathrm{p} 75^{\mathrm{NGFR}} \mathrm{mRNA}$, as shown by the Q-RT-PCR (Fig. 1B) ( $\Delta \Delta$ Ct NGF-treated vs untreated DU145: 4,2 $\pm 0,5 ; \Delta \Delta$ Ct NGF-treated vs untreated PC3: $4,9 \pm 0,6$ ). That the $\mathrm{p} 75^{\mathrm{NGFR}}$ mRNA was translated into protein is demonstrated by the immunocytochemistry experiments reported in Fig. 1C. Untreated DU145 and PC3 cells do not express $\mathrm{p} 75^{\mathrm{NGFR}}$ (Fig. 1C, b, d), while NGF-treated cells showed a positive staining when immunoreacted with the anti-p $75^{\mathrm{NGFR}}$ antibody (Fig. 1C, c, e). The non specific signal obtained by incubating cells with the normal goat serum is reported in Fig. 1C, panel a. PC12 cells were used as positive internal control (Fig. 1C, f).

\section{Gene expression analysis by DNA microarray screening in the DU145 cell line}

To identify the molecular determinants of NGF-mediated effects on the PCa cell line DU145, we studied the gene expression profile in untreated and NGF-treated cells, using the microarraymediated gene screening. Genes showing more than a two-fold increase or decrease in their expression were considered significant in the selection criteria. Comparison of set probes contained

in the Human Genome U133 Plus 2.0 Array GeneChip, suggested that NGF treatment of DU145 cells decreased the expression of 52 known genes, while the expression of 40 known genes was increased. Sixteen of these genes did not have characterized biological functions (not shown). Table 2 shows that, by clustering analysis based on gene function, exposure to NGF induced in DU145 
PCa cells modifications in the expression of genes involved in various aspects of cellular physiology and pathophysiology.

Genes involved in invasion and metastasis. Detailed analysis of gene expression according to their functional annotation evidenced that NGF induced a significant modifications of genes that may facilitate metastasis formation. In particular, LAMP3, that was highly expressed in untreated DU145 cells was inhibited by NGF exposure of about 5-fold. Among NGF-induced genes, we observed that PLEC1, that facilitates cell-matrix adhesion, was about 4-fold increased. Other genes involved in the cell-matrix and cell-cell adhesion such as PXN, LOXL2 and PALPN were induced of about 4-5 fold.

Genes involved in cell proliferation and apoptosis. The inhibition of cell proliferation observed in NGF-treated DU145 cells may find one of its molecular determinant in the reduced levels of genes such as the oncogene $24 \mathrm{p} 3$ or LCN2 (about 5-fold decreased compared to untreated cells) and the cyclin-dependent kinase inhibitor Kip2/p57 (about 3-fold decrease). Genes that reduce cell proliferation and may induce apoptosis, such as the Insulin-like Growth Factor (IGF) binding protein IGFBP3, the apoptosis-related cysteine protease CASP2 and a gene involved in the arrest of cell cycle progression, namely GAS2L3, were significantly increased. In particular, the expression of IGFBP3 and CASP2 was increased of about 3,5-fold, while GAS2L3, was increased of about 8fold.

Genes involved in cell metabolism. Among genes involved in cell metabolism, we would like to highlight on the strong expression of the enzyme that synthesize prostaglandin E, namely PTGES, in untreated DU145 cells. Interestingly, NGF treatment induced a 4-fold decrease of the levels of this gene. Another gene known to be involved in the PCa progression and in the immune surveillance escape is ARG2 (Bronte et al., 2005), that is highly expressed in untreated DU145 cells and it is reduced by NGF treatment of about 3,5-fold. A number of genes involved in different pathways of cell metabolism that are also reduced of about 3,5-4-foldby NGF treatment are the extracellular glycoprotein SEPP1 and the proteolytic enzyme PGPEP1. GALNT2, that is involved 
in the oligosaccharide biosynthesis (2,6-fold induced) and the protease inhibitor SERPINB7 (5fold induced) are increased by NGF treatment.

Genes involved in signal transduction and of transcription factors. Different genes involved in signal transduction as well as various transcription factors were significantly modified by NGF treatment in DU145 cell line. In particular, the gene encoding the ribosomal protein RPL37, that is a component of the 60S subunit and is expressed in untreated DU145 cells was 3,2 fold reduced by NGF. Transcription factors as HES1, belonging to the basic helix-loop-helix family and NR4A2, a member of the steroid-thyroid hormone-retinoid receptor superfamily, were expressed in untreated cells and reduced by about 4 - fold after NGF treatment. On the same line, the signal values of other genes, i.e. the transcription modulator $\mathrm{p} 8$, a nuclear protein with mitogenic activity, and TP53INP1, that regulates cell cycle progression and apoptosis, were about 3,5-fold reduced in NGF-treated cells. Furthermore, a number of genes encoding other transcription factors or transcription factor modulators were increased by NGF treatment, i.e. the transcription factor 3 TCF3 $(+4,2$-fold), the triple functional domain TRIO $(+3,3$-fold $)$, the valyl-tRNA synthetase $\operatorname{VARS}(+3,9$-fold) and the myc-associated zinc finger protein MAZ (+ 7,9-fold).

\section{Q-RT-PCR validation of DNA array analysis}

To validate the gene expression modifications observed with the microarray approach, we chose representative genes for the Q-RT-PCR analysis in control and NGF-treated DU145 cells. In particular, for each cluster, we chose genes that were inhibited as well as genes that were induced by NGF treatment (Table 2, in italic). Preliminary experiments of Q-RT-PCR using serial dilution of cDNA of untreated DU145 were performed, to check specificity and efficiency of our amplification protocol. Fig. 2 reports an example of curves obtained by amplifying the PLEC1 gene (a gene involved in cytoskeletal anchoring), the LCN2 gene (involved in cell differentiation and growth) and the $\beta$-actin as housekeeping gene. Q-RT-PCR amplification from serial dilution of cDNA input of each gene showed high linearity, as indicated by the Pearson correlation coefficient. 
Fig. 3 summarizes the results obtained with the Q-RT-PCR amplification of selected genes in untreated and NGF-treated DU145 cell line. The gene expression modifications were in direct agreement with the microarray data, although the fold change in the expression level was not superimposable for some genes. In particular, among genes involved in invasion and metastasis, our results demonstrated that the mRNA encoding PLEC1 was increased of 2,5-3-fold by NGF, while the LAMP3 mRNA was decreased of about 3-fold. Among genes involved in cell proliferation and apoptosis, IGFBP3 mRNA was expressed at higher level in NGF-treated cells (about 3-fold), while the mRNA encoding LCN2 was significantly inhibited. Experiments conducted to study mRNA encoding selected genes of the transcription factor family demonstrated that HES1, NR4A2 and p8 were inhibited of about 2-3 fold. The expression of mRNA encoding PTGES and ARG2 mRNAs was inhibited by NGF treatment of about -3 -fold and - 5-fold, respectively.

In order to determine whether these genes were selectively modified by NGF treatment only in DU145 cells or whether they may represent general molecular targets for the induced reduction of malignancy in PCa, we investigated their expression by Q-RT-PCR in another NGF-responsive PCa cell line, the PC3 cells. Comparison of gene expression modifications in untreated and NGFtreated PC3 cells showed that NGF induced the same pattern of gene modifications as in DU145 cells (Fig. 4). Interestingly, from a quantitative point of view, we reported different fold of changes of mRNA expression in some genes in PC3 cells compared to DU145 cells after treatment, in line with the different responsiveness to NGF of PCa cell lines (Sigala et al., 1999). Indeed, PLEC1 mRNA was induced at higher level by NGF treatment in PC3 than in DU145 cells, reaching + 7-fold, while mRNA of genes belonging to the transcription factor family were inhibited to a lower level in PC3 cells compared to DU145 cells; in particular: NR4A2, that was 5-fold decrease in DU145 cells, was 2,5-fold reduced in PC3 cells andand HES1 was decreased 8-fold in DU145 cells and 2,5-fold in PC3 cells. 


\section{DISCUSSION}

There is increasing evidence that the NGF system plays a role in the development of prostate cancer. Both NGF and its $\mathrm{p} 75^{\mathrm{NGFR}}$ receptor are, in fact, progressively lost in benign prostate hyperplasia, adenocarcinoma and metastatic cells (Macgrogan et al., 1992; Pflug et al., 1992; Paul et al., 1996; Harper, 1999), while trkA is maintained in all grades of PCa (Pflug et al., 1995), with a suggested mitogenic role (Festuccia et al., 2007). Thus, while trkA mediates the mitogenic effect of NGF, expression of $\mathrm{p} 75^{\mathrm{NGFR}}$ represents a crucial condition for the antiproliferative and differentiating effects of NGF (Sigala et al., 1999; Sigala et al., 2002; Papatsoris et al., 2007), suggesting that $\mathrm{p} 75^{\mathrm{NGFR}}$ could be a tumor suppressor in the prostate (Pflug et al., 1998). On this line, we have reported that NGF treatment of PCa cell lines induces their differentiation into a less malignant phenotype, as shown by the expression of $\mathrm{p} 75^{\mathrm{NGFR}}$ and androgen receptors, decrease of proliferation rate both in vitro and in vivo, decreased in in vitro invasiveness, decrease of telomerase activity and expression of the KAI1 metastasis suppressor gene (Sigala et al., 1999; Sigala et al., 2002). Accordingly, it has been shown that $\mathrm{p} 75^{\mathrm{NGFR}}$ transfection in the PC3 cell line results in the modification of the expression of a number of genes involved in metastasis suppression and differentiation (Nalbandian et al., 2005). The target genes identified by Nalbandian et al. (2005) are different from those presented here and this discrepancy can find its rationale in the distinct study design, as the transfection-induced expression of $\mathrm{p} 75^{\mathrm{NGFR}}$ may allow receptor overexpression. Moreover, it cannot be excluded that the different microarray used can influence the results obtained. It should be observed, however, that the genes identified in the above-mentioned paper and in the present work, although different, can be aggregated as functional classes, namely, cell invasion and metastasis, apoptosis, transduction and transcription, suggesting a level of complexity in the intracellular mechanisms underlying PCa progression that could account for the molecular and clinical heterogeneity of this disease.

In this paper, we report that NGF treatment of the DU145 cell line modifies the expression profile of clusters of genes involved in invasion and metastasis, in cell proliferation and apoptosis, 
inflammation, cell metabolism and transcriptional activity. Some of the genes modified, i.e. ARG2 and IGFBP3, have been already involved in the advancement of PCa (Bronte et al., 2005; Renehan et al., 2004), while we are first demonstrating a correlation of a number of genes, i.e. LAMP3, PTGES, NR4A2, with the progression and the metastasis-promoting features of PCa, with a significant potential for developing clinical prognostic tests that could help to better classify and treat this tumor. Recently, the up-regulation of LMO2 and ETS-transcription factors, whose expression was reduced by NGF treatment in DU145 cells (Table 2), has been as well involved in PCa progression (Ma et al., 2007; Rostad et al., 2007).

Malignant growth is characterized by several key changes: self-sufficiency of growth signals, insensitivity to anti-growth signals, escape from apoptosis, unregulated proliferation potential, enhanced angiogenesis, metastasis, escape from immune surveillance ( $\mathrm{Lu}$ et al., 2006). On these bases, among genes modified by NGF treatment in DU145 cells, we validated representative genes playing a role in different cellular functions.

Invasion and metastasis. Cell motility is a critical determinant of PCa progression. Different genes involved in invasion and metastasis were inhibited in DU145 and PC3 cells by NGF treatment. In particular, the mRNA encoding LAMP3/CD63 lysosomal associated membrane protein 3, a cell membrane protein involved in cell adhesion and motility (Maecker et al., 1997), was from 3- to 5-fold less expressed in treated cells. LAMP3/CD63 is located primarily on lysosomal membranes and it is the major carrier for poly-N-acetyllactosamines, which is a critical ligand for E-selectin present on endothelial cells and platelets. Recently, overexpression of LAMP3/CD63 has been associated with an enhanced metastatic profile in cervical cancer (Kanao et al., 2005). In the present paper, we first suggest a link between the LAMP3/CD63 expression and the PCa progression and it could be hypothesize that NGF-induced reduction of in vitro invasiveness observed in PCa cell lines could be associated to the inhibition of LAMP3/CD63 expression. The pattern of genes involved in the reduction of invasiveness of NGF-treated PCa cell lines included also PLEC1 (plectin 1), belonging to the plakin family, that is increased in DU145 
and PC3 cell lines after NGF exposure. These proteins represent a family of cytolinker proteins that are central components of the connection of adhesive junctions with cytoskeleton, and represent the major mechanism of cell-cell junctions in epithelial cells (Huber, 2003). In line with this, it has been demonstrated that in PCa the composition of basal lamina structure (included PLEC1) is abnormal (Nagle et al., 1995).

Cell proliferation and apoptosis. Among genes involved in DU145 and PC3 cell proliferation and that were inhibited by NGF treatment, we examined LCN2 (lipocalin 2 or oncogene $24 \mathrm{p} 3$ or NGAL, Neutrophil Gelatinase-Associated Lipocalin). Lipocalins are small extracellular proteins with a role in cell proliferation and differentiation, that fulfil a number of biological functions, including lipophilic ligand transport, sensory transduction, prostaglandin synthesis and regulation of cellular homeostasis and immunity (Flower, 1994). NGAL overexpression is observed in different human tumors and in ovarian cancer cell lines (Bratt, 2000). The precise role of lipocalins in cancer, however, is still under investigation, as NGAL is overexpressed in tumor cells induced by neu, but not by ras or in chemically-induced cancers (Stoesz and Gould, 1995). The present data suggest that lipocalin 2 is overexpressed in PCa cell lines and that the differentiating effects elicited by NGF is associated with a reduction of its mRNA expression.

A well known marker of regulation of PCa cell growth is IGFBP3 (Insulin-like Growth Factor Binding Protein 3). Converging results from epidemiological studies and in vivo models indicate that there is a strong correlation between the defective regulation of the IGF network and prostate carcinogenesis (Renehan et al., 2004). IGF-1 is an important agent for carcinogenesis and its bioactivity is modulated by IGF-binding proteins (IGFBPs), by regulating the potential ligand function of free IGF-1 for its receptor (Chan et al., 2002). IGFBP3 inhibits prostate tumor growth also by an IGF-independent mechanism (Silha et al., 2006). Local overexpression of IGFBP3 attenuates prostate tumorigenesis (Silha et al., 2006); here, we demonstrated that the mRNA encoding IGFBP3 is 2 to 3-fold increased in DU145 and PC3 cells following treatment with NGF. 
Inflammation. Several studies support the concept that there is a link between inflammation, cancers and immunity ( $\mathrm{Lu}$ et al., 2006). The expression of the enzyme arginase, produced by the gene ARG2, is related to the immune surveillance and it is highly expressed in cancer of different types (Cederbaum et al., 2004) including PCa. The intratumoral arginase induction favors the cancer progression through different pathways: 1) by providing polyamines, it supports tumor growth and development, 2) by negatively affecting the tumor- infiltrating lymphocyte activity, it suppresses antitumor immune response (Bronte et al., 2005). Accordingly, we detected high level of ARG2, NGF treatment that induces cell differentiation significantly reduced ARG2 mRNA expression.

The PTGES (prostaglandin E synthase) gene has been implicated in inflammation and carcinogenesis (Lu et al., 2006). We report here that PTGES was highly expressed in both DU145 and PC3 cell lines and that it was reduced by NGF treatment. Overproduction of PGE may contribute to carcinogenesis and metastasis, by reducing programmed cell death, by stimulating cell migration and angiogenesis and by reducing the immune surveillance (Lu et al., 2006). Moreover, we found that the member of the nuclear receptor superfamily NR4A2, which is a downstream target of PGE, as its expression is increased by PGE in colorectal cancer (Holla et al., 2006), was decreased in NGF-treated PCa cells. These data suggest that the PTGES/NR4A2 system may play a role not only in the colorectal cancer, but also in PCa.

Transcription factors. In addition to NR4A2, NGF treatment reduced the expression of the transcription factor $\mathrm{p} 8$ candidate of metastasis, that encodes a highly basic polypeptide of 80 aa, belonging to the HMG-I/Y proteins (Mallo et al., 1997), which are essential for the transcription of several genes. Several functions have been ascribed to $\mathrm{p} 8$. Intriguingly, it has been involved in cell cycle regulation, as either a proapoptotic factor (Carracedo et al., 2006) or a factor associated with tumor growth and progression (Mohammad et al., 2004). To account for such different functions, it has been proposed that the small size of the protein, lacking a specific structure, and its 
cytoplasmic/nuclear localization allow interactions with different targets; however, it cannot be excluded that cell or tissue-specific factors may determine the role of $\mathrm{p} 8$ in the control of cell fate.

Another transcription factor whose expression is inhibited by NGF is HES1, that belongs to the family of helix-loop-helix transcription factors known as hairy/enhancer of split (HES) genes. HES is a downstream target of Notch signalling, which affects the development and function of many organs and it is also involved in cell proliferation and apoptosis (Artavanis-Tsakonas et al., 1999; Weng and Aster, 2004). Alteration of these functions in adults has been associated with various types of cancers, i.e. leukemia, breast cancer, hepatocellular carcinomas, in which Notch may act as an oncogene, although contrasting results have been reported (reviewed in Bolos et al., 2007). Interestingly, HES1 shows elevated expression in different clones of PC3 cell lines and promotes lateral motility (Scorey et al., 2006), indicating that our observation of NGF-mediated inhibition of HES1 gene expression may contribute to the reduction of invasiveness observed in NGF-treated DU145 and PC3 cell lines.

In conclusion, the identification of gene/protein alterations and markers of metastasispromoting features at the time of diagnosis is a great challenge in PCa research, that may help to predict a negative or positive clinical outcome. Indeed, the PCa clinical behaviour, including disease progression and metastases, androgen sensitivity, response to chemotherapy/radiotherapy and time to relapse cannot still be predicted. Currently, there are no markers that differentiate clinically relevant from clinically benign disease; thus, better indicators of $\mathrm{PCa}$ presence and progression are needed to avoid unnecessary treatment, to predict disease course and eventually to develop more effective therapies. The data presented here, using the experimental model of NGFinduced reduction of malignancy of PCa cell lines, may help to identify gene/proteins that dispose to relapse and to assess future markers that could allow the development of new clinic diagnostic and therapeutical approaches, promoting an advantageous and patient-beneficial translational research. 


\section{REFERENCES}

Artavanis-Tsakonas, S., Rand, M.D., Lake, R.J., 1999. Notch signalling: cell fate control and signal integration in development. Science 284, 770-776.

Bolos, V., Grego-Bessa, J., de la Pompa, J.L., 2007. Notch signalling in development and cancer. Endocr. Rev. 28:339-363.

Bratt, T., 2000. Lipocalins and cancer. Biochem. Biophys. Acta 1482, 318-326.

Bronte, V., Kasic, T., Gri, G., Gallana, K., Borsellino, G., Marigo, I., Battistini, L., Iafrate, M., Prayer-Galetti, T., Pagano, F., Viola, A., 2005. Boosting antitumor responses of T lymphocytes infiltrating human prostate cancers. J. Exp. Med. 201, 1257-1268.

Carracedo, A., Lorente, M., Egia, A., Blazquez, C., Garcia, S., Giroux, V., Malicet, C., Villuendas, R., Gironella, M., Gonzalez-Feria, L., Piris, M.A., Iovanna, J.L., Guzman, M., Velasco, G., 2006. The stress-regulated protein $\mathrm{p} 8$ mediates cannabinoid-induced apoptosis of tumor cells. Cancer Cell 9, 301-12.

Cederbaum, S.D., Yu, H., Grody, W.W., Kern, R.M., Yoo, P., Iyer, R.K., 2004. Arginases I and II: do their functions overlap. Mol. Genet. Metab. 81, S38-S44.

Chan, J.M., Stampfer, M.J., Ma, J., Gann, P., Gaziano, J.M., Pollak, M., Giovannucci, E., 2002. Insulin-like growth factor-I (IGF-I) and IGF binding protein-3 as predictors of advanced-stage prostate cancer. J. Natl. Cancer Inst. 94, 1099-1106.

Djakiew, D., 2000. Dysregulated expression of growth factors and their receptors in the development of prostate cancer. Prostate 42, 150-60.

Festuccia, C., Muzi, P., Gravina, G.L., Millimaggi, D., Speca, S., Dolo, V., Vicentini, C., Bologna, M., 2007. Tyrosine kinase inhibitor CEP-701 blocks the NTRK1/NGF receptor and limits the invasive capability of prostate cancer cells in vitro. Int. J. Oncol. 30, 193-200.

Flower, D.R., 2000. The lipocalin protein family: a role in cell regulation. FEBS Lett. 354, 7-11.

Harper, G.P., Thoenen, H., 1979. Guinea pig prostate is a rich source of nerve growth factor. Nature (London) 279, 160-162. 
Hasan, W., Smith, H.J., Ting, A.Y., Smith, P.G., 2005. Estrogen alters trkA and p75 neurotrophin receptor expression within sympathetic neurons. J Neurobiol 65, 192-204.

Holla, V.R., Mann, J.R., Shi, Q., DuBois, R.N., 2006. Prostaglandin E2 regulates the nuclear receptor NR4A2 in colorectal cancer. J. Biol. Chem. 28, 2676-82.

Hoon, D.S., Kitago, M., Kim, J., Mori, T., Piris, A., Szyfelbein, K., Mihm, M.C. Jr, Nathanson, S.D., Padera, T.P., Chambers, A.F., Vantyghem, S.A., MacDonald, I.C., Shivers, S.C., Alsarraj, M. Reintgen, D.S., Passlick, B., Sienel, W., Pantel, K., 2006. Molecular mechanisms of metastasis, Cancer Metastasis Rev. 25, 203-20.

Huber, O., 2003. Structure and function of desmosomal proteins and their role in development and disease. Cell. Mol. Life Sci. 60, 1872-1890.

Kanao, H., Enomoto, T., Kimura, T., Fujita, M., Nakashima, R., Ueda, Y., Ueno, Y., Miyatake, T., Yoshizaki,T., Buzard, G.S., Tanigami, A., Yoshino, K., Murata, Y., 2005. Overexpression of LAMP3/TSC403/DC-LAMP promotes metastasis in uterine cervical cancer. Cancer Res. 5, 86408645.

Lu, H., Ouyang, W., Huang, C., 2006. Inflammation, a key event in cancer development. Mol. Cancer Res. 4, 221-233.

Ma, S., Guan, X.Y., Beh, P.S., Wong, K.Y., Chan, Y.P., Yuen, H.F., Vielkind, J., Chan, K.W., 2007. The significance of LMO2 expression in the progression of prostate cancer. J. Pathol. 211: 278-285.

Macgrogan, D., Saint-Andrè, J.-P., Dicou, E., 1992. Expression of nerve growth factor and nerve growth factor receptor genes in human tissues and in prostatic adenocarcinoma cell lines. J. Neurochem. 59, 1381-1391.

Maecker, H.T., Todd, S.C., Levy, S., 1997. The tetraspanin superfamily: molecular facilitators. FASEB J. 11, 428-442.

Mallo, G.V., Fiedler, F., Calvo, E.L., Ortiz, E.M., Vasseur, S., Keim, V., Morisset, J., Iovanna, J.L., 1997. Cloning and Expression of the rat p8 cDNA, a new gene activated in pancreas during the 
acute phase of pancreatitis, pancreatic development, and regeneration, and which promotes cellular growth. J. Biol. Chem. 272, 32360-32369.

Missale, C., Boroni, F., Losa, M., Giovanelli, M., Zanellato, A., Dal Toso, R., Spano, P.F., 1993. Nerve growth factor suppresses the transforming phenotype of human prolactinomas. Proc. Natl. Acad. Sci. USA 90, 7961-7965.

Missale, C., Codignola, A., Sigala, S., Finardi, A., Paez-Pereda, M., Sher, E., Spano, P.F., 1998. Nerve Growth Factor abrogates the tumorigenicity of human small cell lung cancer cell lines. Proc. Natl. Acad. Sci. USA 95, 5366-5371.

Mohammad, H.P., Seachrist, D.D., Quirk, C.C., Nilson, J.H., 2004. Re-expression of p8 contributes to tumorigenic properties of pituitary cells and appears in a subset of prolactinomas in transgenic mice that hypersecrete luteinizing hormone. Mol. Endocrinol. 18, 2583-2593.

Montano, X., Djamgoz, M.B.A., 2004. Epidermal growth factor, neurotrophins and the metastatic cascade in prostate cancer. FEBS Letters 571, 1-8.

Nagle, R.B., Hao, J., Knox, J.D., Dalkin, B.L., Clark, V., Cress, A.E., 1995. Expression of hemidesmosomal and extracellular matrix proteins by normal and malignant human prostate tissue. Am. J. Pathol. 146, 1498-1507.

Nalbandian, A., Pang, A.L.Y., Rennert, O.M., Chan W.-Y, Ravindranath, N., Djakiew, D., 2005. A novel function od fifferentiation revelaled by cDNA microarray profiling of $\mathrm{p} 75^{\mathrm{NTR}}$-regulated gene expression. Differentiation 73, 385-396.

Nickerson Poulin, A., Guerci, A., El Mestikawy, S., Semba, K., 2006. Vesicular glutamate transporter 3 immunoreactivity is present in cholinergic basal forebrain neurons projecting to the basolateral amygdala in rat. J Comp Neurol 498, 690-711.

Ohrt, T., Mancini, A., Tamura, T., Niedenthal, R., 2004. c-Cbl binds to tyrosine-phosphorylated neurotrophin receptor p75 and induces its ubiquitination. Cell Signal 16, 1291-1298. 
Paez Pereda, M., Missale, C., Grubler, Y., Arzt, E., Schaaf, L., Stalla, G.K., 2000. Nerve growth factor and retinoic acid inhibit proliferation and invasion in thyroid tumor cells. Mol. Cell. Endocrinol. 167, 99-106.

Papatsoris, A.G., Liolitsa, D., Deliveliotis, C., 2007. Manipulation of the nerve growth factor network in prostate cancer. Expert Opin Investig Drugs 16, 303-9.

Paul, A.B., Grant, E.S., Habib, F.K., 1996. The expression and localization of $\beta$-nerve growth factor ( $\beta$-NGF) in benign and malignant human prostate tissue: relationship to neuroendocrine differentiation. Br. J. Cancer 74, 1990-1996.

Pflug, B.R., Onoda, M., Lynch, J.H., Djakiew, D., 1992. Reduced expression of the low affinity nerve growth factor receptor in benign and malignant human prostate tissue and loss of expression in four human metastatic prostate tumor cell lines. Cancer Res. 52, 5403-5406.

Pflug, B.R., Dionne, C., Kaplan, D.R., Lynch, J., Djakiew, D., 1995. Expression of a Trk high affinity nerve growth factor receptor in the human prostate. Endocrinol. 136, 262-8.

Pflug, B.R., Djakiew, D., 1998. Expression of $\mathrm{p} 75^{\mathrm{NTR}}$ in a human prostate epithelial tumor cell line reduces nerve growth factor-induced cell growth by activation of programmed cell death. Mol. Carcinog. 23, 106-114.

Renehan, A.G., O'Dwyer, S.T., Shalet, S.M., 2004. Insulin-like growth factor (IGF)-I, IGF binding protein-3, and cancer risk: systemic review and meta-regression analysis. Lancet 363, 1346-1353. Rostad, K., Mannelqvist, M., Halvorsen, O.J., Oyan, A.M., Bo, T.H., Stordrange, L., Olsen, S., Haukaas, S.A., Lin, B., Hood, L., Jonassen, I., Akslen, L.A., Kalland, K.H., 2007. ERG upregulation and related ETS transcription factors in prostate cancer. Int. J. Oncol. 30, 19-32.

Rozen, S., Skaletsky, H., 2000. Primer3 on the WWW for general users and for biologist programmers. In: Krawetz, S., Misener, S. (Eds), Bioinformatics Methods and Protocols: Methods in Molecular Biology. Humana Press, Totowa NJ, pp 365-386. 
Scorey, N., Fraser, S.P., Patel, P., Pridgeon, C., Dallman, M.J., Djamgoz, M.B., 2006. Notch signalling and voltage-gated $\mathrm{Na}(+)$ channel activity in human prostate cancer cells: independent modulation of in vitro motility. Prostate Cancer Prostatic Dis. 9, 399-406.

Sigala, S., Faraoni, I., Botticini, D., Paez-Pereda, M., Missale, C., Bonmassar, E., Spano, P.F., 1999. Suppression of telomerase, re-expression of KAI1, and abrogation of tumorigenicity by nerve growth factor in PCa cell lines. Clin. Cancer Res. 5, 1211-1218.

Sigala, S., Tognazzi, N., Rizzetti, M.C., Faraoni, I., Missale, C., Bonmassar, E., Spano, P.F., 2002. Nerve growth factor induces the re-expression of functional androgen receptors and $\mathrm{p} 75^{\mathrm{NGFR}}$ in the androgen-insensitive prostate cancer cell line DU145. Eur. J. Endocrinol. 147, 407-415.

Silha, J.V., Sheppard, P.C., Mishra, S., Gui,, Y., Schwartz, J., Dodd, J.G., Murphy, L.J., 2006. Insulin-like growth factor (IGF) binding protein-3 attenuates prostate tumor growth by IGFdependent and IGF-independent mechanisms. Endocrinol. 147, 2112-21.

Stoesz, S.P., Gould, M.N., 1995. Overexpression of neu-related lipocalin (NRL) in neu-initiated but not ras or chemically initiated rat mammary carcinomas. Oncogene 11, 2233-2241.

Weng, A.P., Aster, J.C., 2004. Multiple niches for Notch in cancer: context is everything, Curr. Opin. Genet. Dev. 14, 48-54. 


\section{ACKNOWLEDGEMENT}

This work was supported by the Center for the Study of the Prostatic Diseases (E.U.L.O., Ente

Universitario Lombardia Orientale, Brescia, Italy) and by a local grant from the University of Brescia. 
Table 1. Genes and primer oligonucleotide sequences used for the Q-RT-PCR

\begin{tabular}{|c|c|c|}
\hline Genes & PCR product (bp) & Primer sequence $\left(5^{\prime}-3^{\prime}\right)$ \\
\hline ARG2 & 130 & $\begin{array}{l}\text { TGTCGGGGGACTAACCTATC } \\
\text { AGTCTTCGCCTCTTCCTCTG }\end{array}$ \\
\hline HES1 & 111 & $\begin{array}{l}\text { CAACACGACACCGGATAAAC } \\
\text { TTCAGCTGGCTCAGACTTTC }\end{array}$ \\
\hline IGFBP3 & 178 & $\begin{array}{l}\text { TGCCGTAGAGAAATGGAAGA } \\
\text { GAGGCTGCCCATACTTATCC }\end{array}$ \\
\hline LAMP3 & 113 & $\begin{array}{l}\text { AAAAACACTGCAACCACCAG } \\
\text { AAGCTAGGGCCGACTGTAAC }\end{array}$ \\
\hline LCN2 & 159 & $\begin{array}{l}\text { ACCTCCGTCCTGTTTAGGAA } \\
\text { AGCATGCTGGTTGTAGTTGG }\end{array}$ \\
\hline NR4A2 & 175 & $\begin{array}{l}\text { AAGGAACCCAAGAGAGTGGA } \\
\text { TCAGGTAGAAAATGCGCTGT }\end{array}$ \\
\hline P8 & 138 & $\begin{array}{l}\text { CTCTATAGCCTGGCCCATTC } \\
\text { CTCTGAATTCTGCAGCTTGG }\end{array}$ \\
\hline $\mathbf{P 7 5}^{\mathrm{NGFR}}$ & 105 & $\begin{array}{l}\text { TCCCTGTCTATTGCTCCATCC } \\
\text { CTGTTGGCTCCTTGCTTGTTC }\end{array}$ \\
\hline PLEC1 & 150 & $\begin{array}{l}\text { CTTCTGCCACTCACGGATAA } \\
\text { CGAGTTGATGATCTCCCAAA }\end{array}$ \\
\hline PTGES & 102 & $\begin{array}{l}\text { GAACGACATGGAGACCATCTAC } \\
\text { AGGAAGACCAGGAAGTGCAT }\end{array}$ \\
\hline$\beta$ ACTIN & 149 & $\begin{array}{l}\text { TCTTCCAGCCTTCCTTCCTG } \\
\text { CAATGCCAGGGTACATGGTG }\end{array}$ \\
\hline
\end{tabular}

Human specific primers were designed using the Primer3 software (http://frodo.wi.mit.edu) (Rosen et al., 2000). 
Table 2. Genes modified by NGF treatment $(50 \mathrm{ng} / \mathrm{ml}, 8 \mathrm{~d})$ in DU145 cells.

\begin{tabular}{|c|c|c|c|}
\hline & C signal & T signal & $\begin{array}{c}\text { T vs C } \\
\text { fold } \\
\text { change }\end{array}$ \\
\hline \multicolumn{4}{|l|}{ Invasion and metastasis } \\
\hline $\begin{array}{l}\text { NM 014398 LAMP3, lysosomal-associated membrane } \\
\text { protein } 3\end{array}$ & 591,1 & 114,2 & $-5,1$ \\
\hline$\underline{\text { NM } 005574}$ LIM domain only 2 (rhombotin-like 1) (LMO2) & 58,3 & 19,9 & $-2,9$ \\
\hline $\begin{array}{lll}\text { NM 001909 } & \text { CTSD, cathepsin D (lysosomal aspartyl } \\
\text { protease) } & & \end{array}$ & 38,3 & 5,7 & $-6,7$ \\
\hline NM 001195 BFSP1, beaded filament structural protein 1 & 41,8 & 10.1 & $-4,1$ \\
\hline$\underline{\text { NM } 002348}$ LY9, lymphocyte antigen 9 & 26,9 & 3,4 & $-7,9$ \\
\hline$\underline{\text { NM 000445 }} \underline{\text { PLEC1, plectin } 1}$ & 65,9 & 268,4 & $+4,0$ \\
\hline$\underline{\text { NM } 002859}$ PXN, paxillin & 27,3 & 110,7 & $+4,0$ \\
\hline$\underline{\text { NM 002318 }}$ LOXL2, lysyl oxidase-like 2 & 25,9 & 127,9 & $+4,9$ \\
\hline $\begin{array}{l}\text { NM 173462 PAPLN papilin, proteoglycan-like sulfated } \\
\text { glycoprotein }\end{array}$ & 9,2 & 42,8 & $+4,6$ \\
\hline NM 015726 WDR42A WD repeat domain 42A & 5,5 & 22,3 & $+4,5$ \\
\hline \multicolumn{4}{|l|}{ Cell proliferation and apoptosis } \\
\hline NM 005564 LCN2, lipocalin 2 (oncogene 24p3) & 648,3 & 115,1 & $-5,6$ \\
\hline $\begin{array}{lll}\text { NM 006732 } & \text { FOSB }\end{array}$ & 277,3 & 82,5 & $-3,3$ \\
\hline$\underline{\text { NM 058229 }}$ FBXO32, F-box protein 32 & 96,3 & 21,7 & $-4,4$ \\
\hline $\begin{array}{l}\text { NM 000076 CDKN1C, cyclin-dependent kinase inhibitor 1C } \\
\text { (p57, Kip2) }\end{array}$ & 82,5 & 30,0 & $-2,9$ \\
\hline$\underline{\text { NM 004165 }}$ RRAD, Ras-related associated with diabetes & 76,8 & 12,3 & $-6,2$ \\
\hline
\end{tabular}




\begin{tabular}{|c|c|c|c|}
\hline $\begin{array}{l}\text { NM 000598 IGFBP3, insulin-like growth factor binding } \\
\text { protein } 3\end{array}$ & 218,9 & 767,1 & $+3,5$ \\
\hline$\underline{\text { NM 032982 }}$ CASP2, caspase 2 & 17,9 & 64,7 & $+3,6$ \\
\hline NM 174942 GAS2L3, growth arrest-specific 2 like 3 & 6,2 & 50,1 & $+8,1$ \\
\hline NM 002612 DLEU2, deleted in lymphocytic leukemia, 2 & 4,5 & 10,2 & $+2,2$ \\
\hline $\begin{array}{lllll}\text { NM 005967 } & \text { NAB2, NGFI-A binding protein } 2 \text { (EGR1 } \\
\text { binding protein 2) } & & & & \\
\end{array}$ & 2,4 & 43,8 & $+18,2$ \\
\hline \multicolumn{4}{|l|}{ Different aspects of cellular metabolism } \\
\hline$\underline{\text { NM } 004878}$ PTGES, prostaglandin E synthase & 1251,5 & 317 & $-3,9$ \\
\hline NM 001172 $A R G 2$, arginase, type $I I$ & 408,2 & 118,3 & $-3,4$ \\
\hline $\begin{array}{l}\text { NM 001035530 SGNE1, secretory granule, neuroendocrine } \\
\text { protein } 1\end{array}$ & 48,1 & 8,6 & $-5,5$ \\
\hline$\underline{\text { NM } 015692} \mathrm{C} 3$, complement component 3 & 47,6 & 7,4 & $-6,4$ \\
\hline$\underline{\text { NM } 005410}$ SEPP1, selenoprotein P 1 & 37,2 & 9,5 & $-3,9$ \\
\hline NM 017712 PGPEP1 pyroglutamyl-peptidase I & 34,7 & 10,2 & $-3,4$ \\
\hline 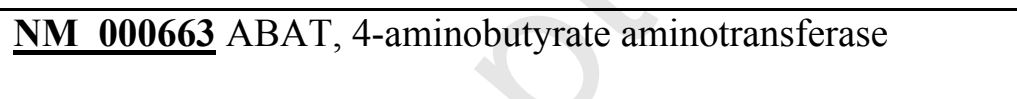 & 31 & 8,6 & $-3,6$ \\
\hline$\underline{\text { NM 002557 Oviductin }}$ & 28,9 & 10,2 & $-2,8$ \\
\hline $\begin{array}{l}\text { NM 018964 SLC37A1 Solute carrier family } 37 \text { (glycerol-3- } \\
\text { phosphate transporter), member } 1\end{array}$ & 25,2 & 3,2 & $-7,8$ \\
\hline NM 019080 NDFIP2, Nedd4 family interacting protein 2 & 23,6 & 6 & $-3,9$ \\
\hline $\begin{array}{l}\text { NM 020133 AGPAT, 1-acylglycerol-3-phosphate O- } \\
\text { acyltransferase } 4\end{array}$ & 20,3 & 2,7 & $-7,5$ \\
\hline NM 001039049 COX8C, cytochrome c oxidase subunit 8C & 16,6 & 1,6 & $-10,3$ \\
\hline$\underline{\text { NM 002729 }}$ MSTP9 macrophage stimulating, pseudogene 9 & 15,8 & 2,1 & $-7,5$ \\
\hline NM 004481GALNT2 UDP-N-acetyl-alpha-D-galactosamine: & 73,7 & 189,8 & $+2,6$ \\
\hline
\end{tabular}




\begin{tabular}{|c|c|c|c|}
\hline \multicolumn{4}{|l|}{ polypeptide $\mathrm{N}$-acetylgalactosaminyltransferase 2} \\
\hline $\begin{array}{l}\text { NM 001040147 SERPINB7, serine (or cysteine) proteinase } \\
\text { inhibitor }\end{array}$ & 7,9 & 40,6 & $+5,1$ \\
\hline NM 004117 FKBP5, FK506 binding protein & 2,8 & 20,6 & $+13,5$ \\
\hline \multicolumn{4}{|l|}{ Transcription and translation, signal transduction } \\
\hline NM_000997 RPL37, ribosomal protein L37 & 1099,9 & 339,8 & $-3,2$ \\
\hline NM 012385 $p 8$ protein (candidate of metastasis 1) & 608,3 & 171,4 & $-3,5$ \\
\hline $\begin{array}{l}\text { NM_033285 TP53INP1, tumor protein p53 inducible nuclear } \\
\text { protein } 1\end{array}$ & 225,1 & 60,1 & $-3,7$ \\
\hline NM 005524 HES1, hairy and enhancer of split 1 & 203,6 & 49,4 & $-4,1$ \\
\hline $\begin{array}{l}\text { NM_006186 NR4A2, nuclear receptor subfamily 4, group A, } \\
\text { member } 2\end{array}$ & 177,6 & 37,9 & $-4,6$ \\
\hline NM_017644 DRE1 protein & 99,2 & 27,4 & $-3,6$ \\
\hline NM_172193 KLHDC1, kelch domain containing 1 & 65,4 & 19,1 & $-3,4$ \\
\hline $\begin{array}{l}\text { NM_198503 KCNT2, potassium channel, subfamily } \mathrm{T} \text {, } \\
\text { member } 2\end{array}$ & 64,8 & 17,5 & $-3,7$ \\
\hline $\begin{array}{l}\text { NM_001001928 PPARA, peroxisome proliferative activated } \\
\text { receptor, alpha }\end{array}$ & 62 & 17,6 & $-3,5$ \\
\hline NM 004433 ETS-related transcription factor (ERT) & 61,1 & 26,4 & $-2,3$ \\
\hline NM_004898 CLOCK, clock homolog & 39,1 & 7,2 & $-5,4$ \\
\hline $\begin{array}{l}\text { NM_004915 ABCG1, ATP-binding cassette, sub-family G } \\
\text { (WHITE), member } 1\end{array}$ & 32,9 & 5,4 & $-6,0$ \\
\hline NM_001012957 DISC1, disrupted in schizophrenia 1 & 28,7 & 8,4 & $-3,4$ \\
\hline NM 145170 TTC18, tetratricopeptide repeat domain 18 & 19,1 & 5,1 & $-3,7$ \\
\hline
\end{tabular}




\begin{tabular}{|c|c|c|c|}
\hline NM 013304 ZDHHC1, Zinc finger DHHC-type containing 1 & 19 & 4,8 & $-3,9$ \\
\hline NM_018328 MBD5, methyl-CpG binding domain protein 5 & 17,5 & 3,4 & $-5,1$ \\
\hline NM_006295 VARS, valyl-tRNA synthetase & 25,7 & 99,5 & $+3,9$ \\
\hline$\underline{\text { NM } 003200}$ TCF3, transcription factor 3 & 12,8 & 53,7 & $+4,2$ \\
\hline NM 031946 CENTG3 centaurin, gamma 3 & 12 & 62,3 & $+5,1$ \\
\hline NM_015908 ARS2 arsenate resistance protein & 10,4 & 57,2 & $+5,5$ \\
\hline$\underline{\text { NM } 007118}$ TRIO, triple functional domain & 10,3 & 34,6 & $+3,3$ \\
\hline NM 001032283 TMPO, thymopoietin & 5,4 & 25,6 & $+4,7$ \\
\hline NM 014264 PLK4, polo-like kinase 4 & 4,6 & 19,2 & $+4,1$ \\
\hline NM_002383 MAZ, MYC-associated zinc finger protein & 3,9 & 29,1 & $+7,4$ \\
\hline $\begin{array}{l}\text { NM 006521 TFE3, transcription factor binding to IGHM } \\
\text { enhancer } 3\end{array}$ & 3,3 & 17,2 & $+5,2$ \\
\hline$\underline{\text { NM } 153034}$ ZFN488, zinc finger protein & 3,3 & 24,2 & $+7,3$ \\
\hline NM_006293 TYRO3, TYRO3 protein tyrosine kinase & 3,2 & 17,7 & $+5,5$ \\
\hline NM 015033 FNBP1, formin binding protein 1 & 3 & 18,9 & $+6,3$ \\
\hline NM 052970 HSPA12B heat shock protein 12B & 3 & 29,2 & $+9,7$ \\
\hline $\begin{array}{l}\text { NM_145185 MAP2K7, mitogen-activated protein kinase } \\
\text { kinase } 7\end{array}$ & 2,6 & 26,5 & $+10,1$ \\
\hline NM_005967NAB2, NGFI-A binding protein 2 & 2,4 & 43,8 & $+18,1$ \\
\hline $\begin{array}{l}\text { NM 016340 RAPGEF6, Rap guanine nucleotide exchange } \\
\text { factor (GEF) } 6\end{array}$ & 2 & 9,7 & $+4,8$ \\
\hline \multicolumn{4}{|l|}{ Miscellaneous } \\
\hline NM 001033047 NPNT nephronectin & 77,6 & 17,4 & $-4,4$ \\
\hline NM 080546 CDW92, member of the choline transporter-like & 46,7 & 13,9 & $-3,4$ \\
\hline
\end{tabular}




\begin{tabular}{|c|c|c|c|}
\hline protein family & & & \\
\hline$\underline{\text { NM } 138796}$ SPATA17 spermatogenesis associated 17 & 26,6 & 4,8 & $-5,5$ \\
\hline \multicolumn{4}{|l|}{ NM 002260 KLRC2, killer cell lectin-like receptor subfamily } \\
\hline C, member 2 & 25,1 & 3,8 & $-6,6$ \\
\hline NM 017541 CRYGS, crystallin gamma $\mathrm{S}$ & 20 & 3 & $-6,6$ \\
\hline$\underline{\text { NM } 013433}$ TNPO2, transportin 2 & 2,8 & 12,9 & $+4,4$ \\
\hline NM 014964 EPN, epsin 2 & 1,8 & 14 & $+7,7$ \\
\hline NM 015120.4 ALM1 Alstrom syndrome 1 & 5,7 & 17,1 & $+3,0$ \\
\hline
\end{tabular}

C: untreated (control) cells; T: NGF-treated cells. In italic, genes studied in the Q- RT-PCR amplification 
Fig. 1. Effects of NGF treatment on DU145 and PC3 PCa cell lines.

A. Cell proliferation rate. DU145 cells were exposed to $50 \mathrm{ng} / \mathrm{ml} \mathrm{NGF}$ for 8 days, PC3 were exposed to NGF for 14 days. Cell count was conducted as described in Materials and Methods. Results are the mean \pm SEM of six different dishes for each cell culture.

$* \mathrm{p}<0.001$ vs untreated cells.

B: Q-RT-PCR detection of $\mathbf{p 7 5}^{\text {NGFR }}$ mRNA. One $\mu \mathrm{g}$ of total RNA from untreated and NGFtreated cells was transcribed in cDNA as described in Materials and Methods. Amplification and detection using the SYBR Green I were performed with the iCYCLER iQ Real Time PCR Detection System. Gene expression levels were normalized by $\beta$-actin and data were analyzed according to the comparative $\mathrm{Ct}$ method, as described in Materials and Methods.

C: Immunocytochemistry. Untreated and NGF-treated DU145 and PC3 cells were plated on polylysine-treated coverslips and processed as described. Cells were fixed for $5 \mathrm{~min}$ at $-20^{\circ} \mathrm{C}$ in cold methanol, permeabilized and incubated with a 1:1000 dilution of the goat polyclonal antibody $(0,2 \mu \mathrm{g} / \mathrm{ml})$ raised against the epitope mapping at the C-terminus of human $\mathrm{p} 75^{\mathrm{NGFR}}$, as described in Materials and Methods. After extensive washes, the appropriate biotinylated secondary antibody was applied and cells were treated according to the supplier's instructions of the ABC kit. Magnification: 40x. a: normal goat serum (blank), b: untreated DU145 cells, c: NGF-treated DU145 cells; d: untreated PC3 cells; e: NGF-treated PC3 cells, f: PC12 cells (positive control).

Fig. 2. Q-RT-PCR amplification from different amounts of cDNA input from selected genes showed high linearity. 
Fig. 3. Comparison of difference in gene expression of selected genes in NGF-treated DU145 vs untreated DU145 cells.

One $\mu \mathrm{g}$ of total RNA from untreated and NGF-treated DU145 (50 ng/ml, 8 days) was transcribed in cDNA as described in Materials and Methods. Amplification and detection using the SYBR Green I were performed with the iCYCLER iQ Real Time PCR Detection System. Gene expression levels were normalized by $\beta$-actin and data were analyzed according to the comparative $\mathrm{Ct}$ method.

Fig. 4. Comparison of difference in gene expression of selected genes in NGF-treated PC3 vs untreated PC3 cells.

One $\mu \mathrm{g}$ of total RNA from untreated and NGF-treated PC3 cells (100 ng/ml, 14 days) was transcribed in cDNA as described in Materials and Methods. Amplification and detection using the SYBR Green I were performed with the iCYCLER iQ Real Time PCR Detection System. Gene expression levels were normalized by $\beta$-actin and data were analyzed according to the comparative Ct method. 
A

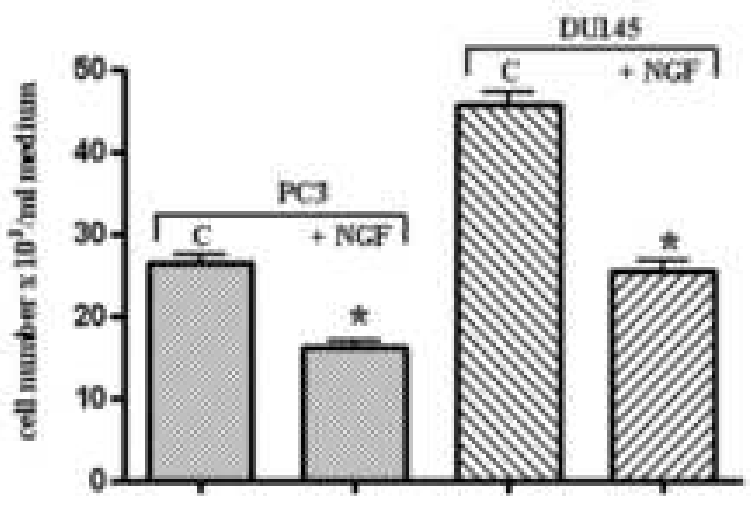

C

a

d

e
B

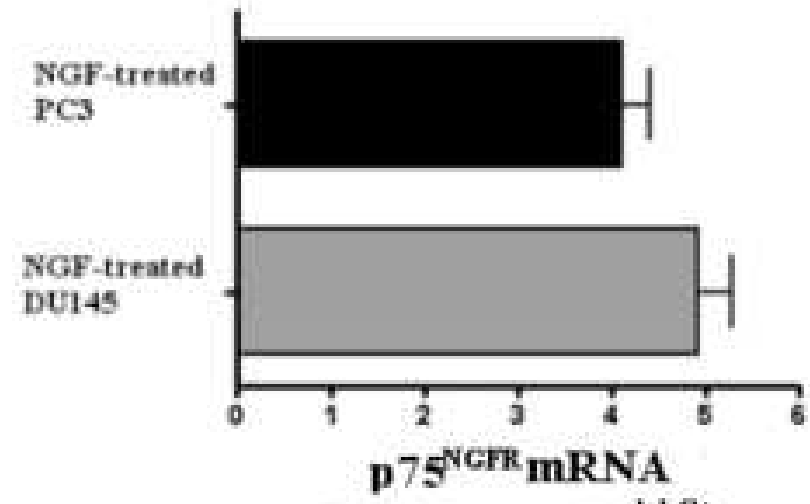

Fold change $(2-\triangle \Delta C$ )
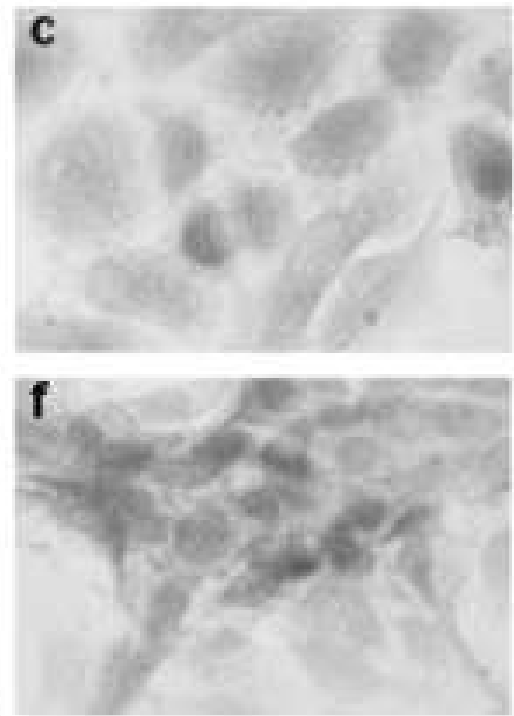


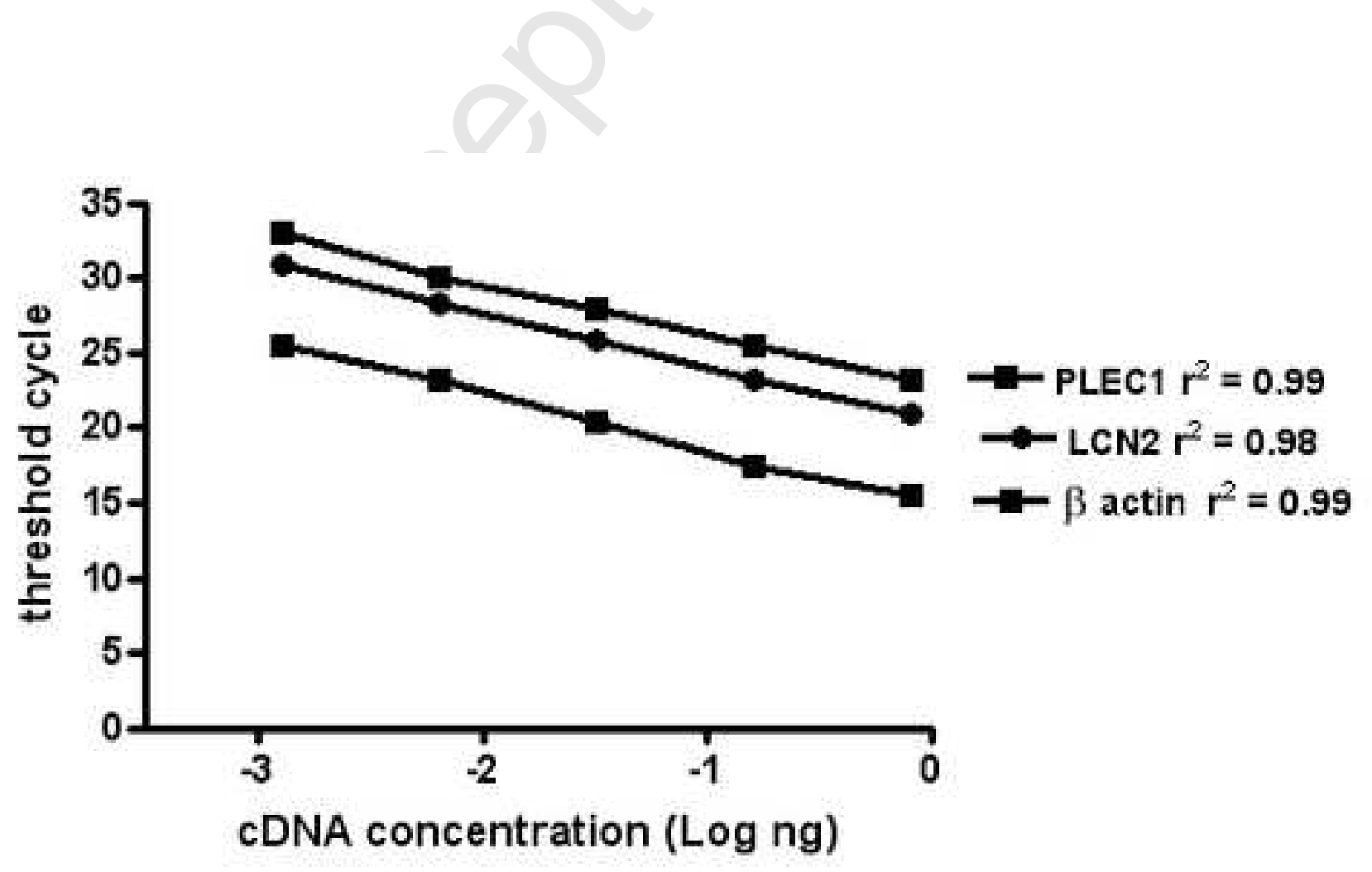

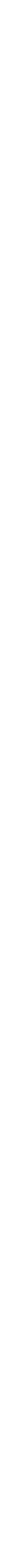




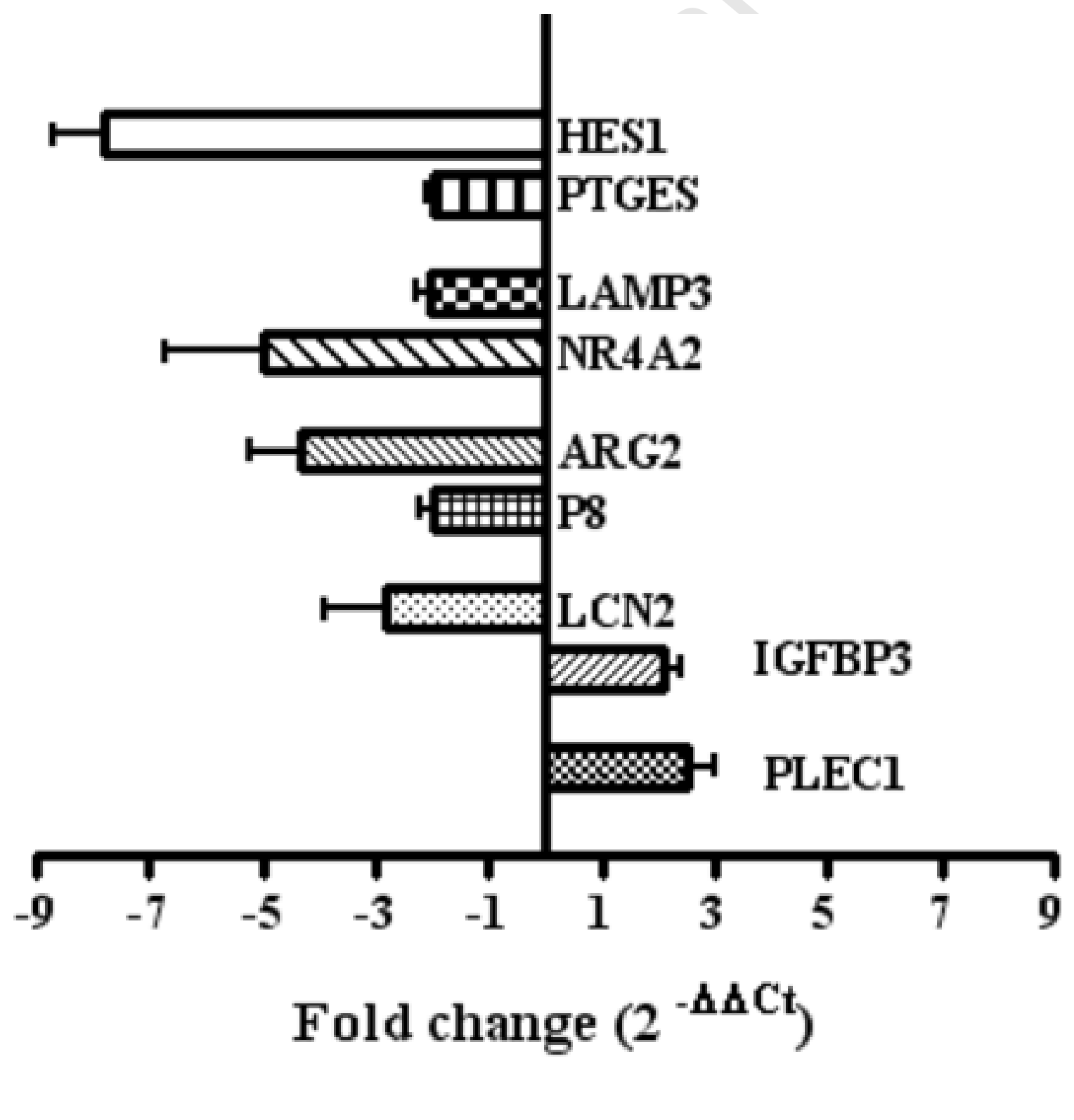

\section{HES1}

PTGES

NR4A2

ARG2

P8

$\mathrm{LCN} 2$

IGFBP3

PLEC1

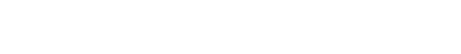

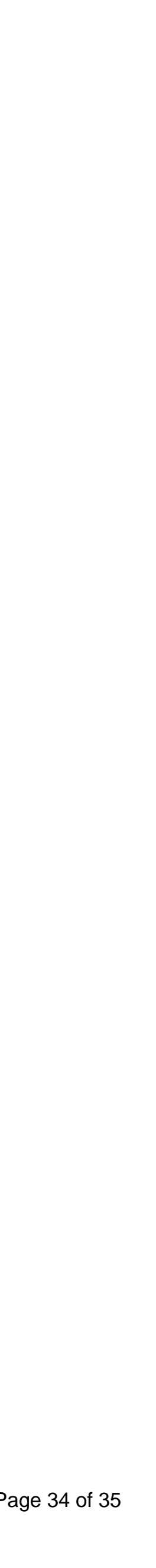




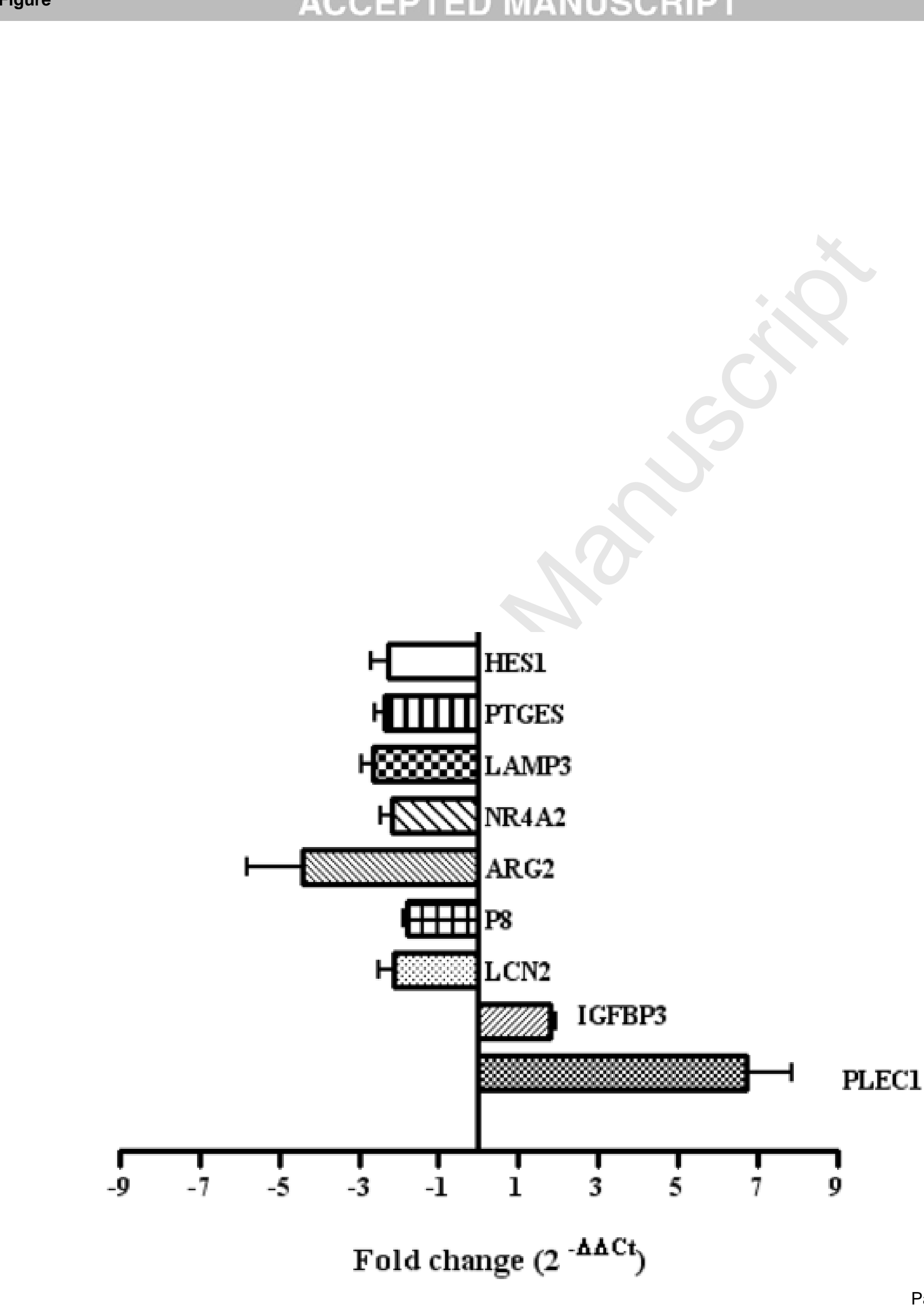

\section{PLEC1}

3

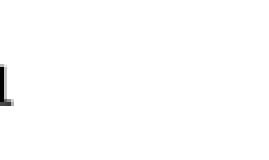

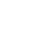

Fold change (2 